\title{
Association of thyroid hormone with body fat content and lipid metabolism in euthyroid male patients with type 2 diabetes mellitus: a cross-sectional study
}

\author{
Xia Sun ${ }^{1 *}$, Liping Chen ${ }^{2}$, Rongzhen $\mathrm{Wu}^{3}$, Dan Zhang ${ }^{4}$ and Yinhui $\mathrm{He}^{4}$
}

\begin{abstract}
Background: This study aimed to explore the associations of thyroid hormones with body fat content and lipid metabolism in euthyroid male patients with type 2 diabetes mellitus (T2DM).

Methods: In January 2017, a cross sectional study, 66 male patients with T2DM who met the World Health Organization diagnostic criteria of 1999 who were $\geq 18.0$ years and had normal thyroid function were recruited at a tertiary hospital. The categories of thyroid hormones (free triiodothyronine [FT3], free thyroxine [FT4], and thyroidstimulating hormone [TSH]) were divided into three groups according to tertiles of thyroid hormones.

Results: The mean FT3, FT4, and TSH of the patients were $2.56 \mathrm{pg} / \mathrm{mL}, 1.03 \mathrm{ng} / \mathrm{dL}$, and $1.50 \mu \mathrm{lU} / \mathrm{mL}$, respectively. Increased FT3 were associated with higher body mass index (BMI) $(P<0.001)$, body fat percentage (BFP) $(P=0.008)$, visceral fat content $(V F C)(P=0.019)$, adiponectin $(P=0.037)$, tumor necrosis factor alpha (TNF-a $)(P<0.001)$, and interleukin $6(\mathrm{IL}-6)(P=0.015)$. There were significant differences among the different FT4 categories for BMI $(P=$ 0.033), waist-hip ratio (WHR) $(P=0.030)$, low-density lipoprotein cholesterol $(L D L-C)(P=0.014)$, and IL-6 $(P=0.009)$. Increased TSH could increase the total cholesterol $(T C)(P=0.005)$ and high-density lipoprotein cholesterol (HDL-C) $(P=0.010)$. FT3 was positively correlated with BMI $(r=0.45 ; P<0.001)$, WHR $(r=0.27 ; P=0.028)$, BFP $(r=0.33 ; P=$ $0.007)$, VFC $(r=0.30 ; P=0.014)$, adiponectin $(r=0.25 ; P=0.045)$, TNF- $a(r=0.47 ; P<0.001)$, and IL-6 $(r=0.32 ; P=$ $0.008)$. FT4 was positively correlated with HDL-C $(r=0.26 ; P=0.038)$, LDL-C $(r=0.26 ; P=0.036)$, and adiponectin $(r=$ $0.28 ; P=0.023)$. TSH was positively correlated with TC $(r=0.36 ; P=0.003)$.
\end{abstract}

Conclusion: This study found that the changes in thyroid hormones are associated with various body fat content and lipid metabolism in euthyroid male patients with T2DM.

Keywords: Type 2 diabetes mellitus, Thyroid hormone, Body fat content, Lipid metabolism, Cross-sectional study

\section{Background}

The prevalence of type 2 diabetes mellitus (T2DM) is a prominent global public health problem, accounting for

\footnotetext{
*Correspondence: sunls007@126.com

'Department of Endocrinology, Lishui Hospital of Traditional Chinese Medicine, No. 800 Zhongshan Street, Liandu District, Lishui, Zhejiang 323000, China

Full list of author information is available at the end of the article
}

approximately 415 million cases globally, and the prevalence of T2DM is predicted to increase to 642 million in 2040 [1]. T2DM could induce excessive risks of cardiovascular disease, neuropathy, nephropathy, retinopathy, and microvascular complications. Moreover, the economic burden of diabetes globally was $\$ 1.31$ trillion and accounted for approximately $1.8 \%$ of the global gross domestic product [2]. Studies showed that insulin

(c) The Author(s). 2021 Open Access This article is licensed under a Creative Commons Attribution 4.0 International License, which permits use, sharing, adaptation, distribution and reproduction in any medium or format, as long as you give appropriate credit to the original author(s) and the source, provide a link to the Creative Commons licence, and indicate if changes were made. The images or other third party material in this article are included in the article's Creative Commons licence, unless indicated otherwise in a credit line to the material. If material is not included in the article's Creative Commons licence and your intended use is not permitted by statutory regulation or exceeds the permitted use, you will need to obtain permission directly from the copyright holder. To view a copy of this licence, visit http://creativecommons.org/licenses/by/4.0/ The Creative Commons Public Domain Dedication waiver (http://creativecommons.org/publicdomain/zero/1.0/) applies to the data made available in this article, unless otherwise stated in a credit line to the data. 
resistance was common in T2DM and metabolic syndrome $[3,4]$. Insulin resistance was a risk factor for stroke and end-stage renal disease [5]. Obesity is the basis of insulin resistance because of the harmful effects of excess fat accumulation on glucose metabolism, which causes functional impairments in metabolic pathways of several areas such as adipose tissue and peripheral organs, like the liver, heart, pancreas, and muscles [6].

Thyroid hormones, including thyroxine and triiodothyronine, regulate the synthesis, mobilization, and breakdown of lipids. Thyroid hormones are closely related to obesity, and slight changes in serum thyroid hormone level can cause local fat accumulation and increased body mass [7, 8]. The thyrotropin receptor (TSHR) has long been considered as a key regulator of thyroid function [9]. Recent studies have shown that thyroid-stimulating hormone (TSH) can also bind directly to TSHR in tissues outside the thyroid to exert external effects, such as in the adipose tissue and liver [10]. The role of thyroid function in energy metabolism has been extensively studied, but traditional viewpoints only emphasize the role of hypothyroidism or subclinical hypothyroidism $(\mathrm{SCH})$ in obesity. Among patients with obesity but with normal thyroid function, thyroid hormones, especially TSH, are significantly different from that of people of healthy weight. This manifests as higher TSH, free triiodothyronine (T3), and free thyroxine (T4) levels in obese patients than those in healthy people $[11,12]$. The incidence of thyroid diseases in patients with T2DM is significantly increased, especially $\mathrm{SCH}$, and is more common in women than men [13, 14]. However, the relationship among TSH, FT3, FT4, body fat content, and lipid metabolism in T2DM patients with normal thyroid function has not been reported. Therefore, in this study, we aimed to explore the association of thyroid hormone levels with body fat content and lipid metabolism in euthyroid male patients with T2DM.

\section{Methods}

\section{Study design and subjects}

This cross-sectional study recruited euthyroid male patients with T2DM admitted in a tertiary hospital on January 2017. This study was approved by the ethics committee of Lishui Municipal Central Hospital (ethics no. 2016-26). All patients provided informed consent for the inclusion in the study. Male patients with T2DM who met the World Health Organization diagnostic criteria of 1999 who were $\geq 18.0$ years and with normal thyroid function were included. Patients with diabetes with acute complications, pulmonary and cardiac diseases, liver and kidney disorder, or clinical and subclinical thyroid diseases were excluded. Finally, 66 patients were included in the final analysis.

\section{Data collection \\ Baseline characteristics}

Baseline data was collected from all participants, including age, anthropometric, and laboratory measurements. Blood pressure was recorded, with the systolic and diastolic blood pressure measured at sitting position, and mean blood pressure was calculated. After $12 \mathrm{~h}$ of fasting overnight, blood from the elbow vein was collected into two sample tubes. The serum was centrifuged from one tube within $2 \mathrm{~h}$, and hematological parameters were determined immediately. Fasting blood glucose (FBG) was detected by hexokinase (Abbott, Abbott Park, IL, USA), fasting insulin (FIns) by chemiluminescence (Abbott), and glycosylated hemoglobin (HbA1C) by ion chromatography (Tosoh, Tokyo, Japan). The insulin resistance index (Homeostatic Model Assessment of Insulin Resistance [HOMA-IR]) was calculated by the minimum homeostasis model. The formula was FBG*FINS/22.5.

\section{Thyroid hormones}

Blood TSH, FT3, and FT4 were detected by chemiluminescence (Abbott) (normal reference ranges: TSH, 0.34$5.60 \mu \mathrm{IU} / \mathrm{mL} ; \mathrm{FT} 3,1.71-3.71 \mathrm{pg} / \mathrm{mL}$; FT4, $0.70-1.48 \mathrm{ng} /$ dL). The TSH, FT3, and FT4 were divided into 3 groups based on the tertiles of thyroid hormones, and each group included 22 patients.

\section{Body fat content}

Height $(\mathrm{m})$, weight $(\mathrm{kg})$, waist circumference, and body mass index (BMI; $\mathrm{kg} / \mathrm{m}^{2}$ ) were measured by uniformly trained nurses for all subjects. Body fat percentage (BFP) and visceral fat content (VFC) were measured by direct segmental impedance measurement (InBody 720 human body composition analyzer; Baisibeisi Medical Equipment Trading Co., Ltd., Shanghai, China).

\section{Lipid metabolism}

After $12 \mathrm{~h}$ of fasting overnight, total cholesterol (TC) was measured by CHOD-PAP (Zhongya Company, Hangzhou, China), triglyceride (TG) by GPO-PAP (Zhongya Company), and high- and low-density lipoprotein (HDL-C and LDL-C, respectively) by homogeneous direct method (Zhongya Company). After adding anticoagulant to the other tube, the plasma was centrifuged and preserved at $-70^{\circ} \mathrm{C}$ for the determination of adiponectin, leptin, visfatin, and tumor necrosis factor alpha $(\mathrm{TNF}-\alpha)$. Shanghai Enzyme-linked Biotechnology Co., Ltd. (Shanghai, China) performed the laboratory determination. The standard curves were $0.156-10 \mathrm{ng} / \mathrm{mL}$ for plasma adiponectin, $0-50 \mathrm{ng} / \mathrm{mL}$ for leptin, $0.1-1000 \mathrm{ng} /$ $\mathrm{mL}$ for visfatin, and $2.5-80 \mathrm{pg} / \mathrm{mL}$ for plasma TNF- $\alpha$. 


\section{Statistical analysis}

All data were processed by SPSS version 21.0 statistical software (IBM Corp., Armonk, NY, USA). Continuous variables were first tested for normality. Normally distributed continuous variables were expressed by mean \pm standard deviation, and multigroup comparison was conducted by analysis of variance and post-test (Student-Newman-Keuls $q$ value). Linear correlation analysis was used for the associations of thyroid hormones with body fat content and lipid metabolism in euthyroid male patients with T2DM. All reported $P$ values are two-sided, and $P$ values $<0.05$ were considered statistically significant.

\section{Patient and public involvement}

Patient and public involvement were not involved in the study design.

\section{Results}

\section{Baseline characteristics}

Of 66 included patients, the mean age was 49.70 years. Moreover, the mean FT3, FT4, and TSH levels of the patients were $2.56 \pm 0.43 \mathrm{pg} / \mathrm{mL}, \quad 1.03 \pm 0.14 \mathrm{ng} / \mathrm{dL}$, and $1.50 \pm 0.74 \mu \mathrm{IU} / \mathrm{mL}$, respectively. The mean FBG, FIns, HOMA-IR, and HbA1c of patients were $10.07 \pm 4.69$ $\mathrm{mmol} / \mathrm{L}, \quad 8.32 \pm 6.14 \mathrm{uU} / \mathrm{mL}, \quad 3.21 \pm 1.97$, and $9.74 \% \pm$ $2.23 \%$, respectively. The body fat content and lipid metabolism of the patients are summarized in Table 1.

\section{FT3}

The distribution of the body fat content and lipid metabolism according to FT3 are shown in Table 2. There were significant differences in BMI $(P<0.001)$, BFP $(P=0.008)$, VFC $(P=0.019)$, adiponectin $(P=0.037)$, TNF- $\alpha(P<0.001)$, and IL-6 $(P=0.015)$ among the FT3 categories, but there were no significant differences in waist-hip ratio (WHR) $(P=0.125)$, TG $(P=0.184)$, TC $(P=0.383)$, HDL-C $(P=0.082)$, LDL-C $(P=0.336)$, leptin $(P=0.123)$, visfatin $(P=0.566)$, homocysteine $(P=0.951)$, or uric acid $(P=0.869)$. The pairwise comparison showed the following: the lowest category of FT3 was associated with lower BMI, as compared with the middle (mean difference $[\mathrm{MD}],-2.76 ; 95 \%$ confidence interval [CI], -4.64 to $-0.89 ; P<0.05)$ and highest categories of FT3 (MD, $-3.60 ; 95 \% \mathrm{CI},-5.43$ to $-1.76 ; P<0.05$ ); the lowest (MD, $-4.84 ; 95 \% \mathrm{CI},-8.10$ to $-1.57 ; P<0.05$ ) and middle categories of FT3 (MD, - 4.19; 95\% CI, 7.49 to $-0.88 ; P<0.05)$ were associated with lower BFP, as compared with the highest category of FT3; the lowest (MD, $-21.51 ; 95 \% \mathrm{CI},-37.02$ to $-6.00 ; P<0.05$ ) and middle categories of FT3 (MD, - 16.39; 95\% CI, 32.09 to $-0.69 ; P<0.05)$ were associated with lower VFC, as compared with the highest category of FT3; the lowest category of FT3 was associated with lower adiponectin, as compared with the middle (MD, $-0.52 ; 95 \%$
Table 1 Baseline characteristics of included patients

\begin{tabular}{|c|c|}
\hline Parameter & Baseline \\
\hline Age & $49.70 \pm 9.45$ \\
\hline TSH & $1.50 \pm 0.74$ \\
\hline FT3 & $2.56 \pm 0.43$ \\
\hline FT4 & $1.03 \pm 0.14$ \\
\hline FPG & $10.07 \pm 4.69$ \\
\hline Fasting insulin & $8.32 \pm 6.14$ \\
\hline HOMA-IR & $3.21 \pm 1.97$ \\
\hline GGT & $48.09 \pm 39.61$ \\
\hline $\mathrm{HbA1c} \%$ & $9.74 \pm 2.23$ \\
\hline MAP & $97.83 \pm 12.81$ \\
\hline BMl & $25.29 \pm 3.40$ \\
\hline WHR & $0.93 \pm 0.05$ \\
\hline BFP & $23.74 \pm 5.82$ \\
\hline VFC & $110.67 \pm 27.28$ \\
\hline TG & $2.00 \pm 1.57$ \\
\hline TC & $4.72 \pm 1.30$ \\
\hline $\mathrm{HDL}$ & $1.03 \pm 0.25$ \\
\hline LDL & $2.72 \pm 0.96$ \\
\hline Adiponectin & $5.35 \pm 0.72$ \\
\hline Leptin & $3.17 \pm 0.36$ \\
\hline Visfatin & $29.14 \pm 3.16$ \\
\hline TNF-a & $17.99 \pm 2.52$ \\
\hline IL-6 & $11.59 \pm 1.46$ \\
\hline Homocysteine & $9.30 \pm 1.95$ \\
\hline UA & $325.94 \pm 88.21$ \\
\hline
\end{tabular}

*BFP body fat percentage, $B M I$ body mass index, $F B G$ fasting blood glucose, $H D L$ high-density lipoprotein, $L D L$ low-density lipoprotein, MAP mean arterial pressure, WHR waist-hip ratio, TC total cholesterol, TG triglyceride, UA uric acid, VFC visceral fat content

CI, -0.95 to $-0.10 ; P<0.05)$ and highest categories of FT3 (MD, -0.43 ; 95\% CI, -0.84 to $-0.01 ; P<0.05$ ); the lowest category of FT3 was associated with lower TNF$\alpha$, as compared with the middle (MD, -2.36 ; 95\% CI, 3.72 to $-1.00 ; P<0.05)$ and highest categories of FT3 (MD, $-2.79 ; 95 \% \mathrm{CI},-4.12$ to $-1.46 ; P<0.05$ ); the lowest category of FT3 was associated with lower IL-6, as compared with the middle (MD, $-0.91 ; 95 \% \mathrm{CI},-1.76$ to $-0.06 ; P<0.05)$ and highest categories of FT3 (MD, $-1.20 ; 95 \% \mathrm{CI},-2.02$ to $-0.37 ; P<0.05)$. Furthermore, we noted that FT3 was positively correlated with BMI $(\mathrm{r}=0.45 ; P<0.001)$, WHR $(r=0.27 ; P=0.028)$, BFP $(r=$ $0.33 ; P=0.007)$, VFC $(r=0.30 ; P=0.014)$, adiponectin $(r=0.25 ; P=0.045)$, TNF- $\alpha(r=0.47 ; P<0.001)$, and IL-6 $(r=0.32 ; P=0.008)$ (Table 3$)$.

\section{FT4}

The distribution of body fat content and lipid metabolism according to FT4 are shown in Table 2. We 
Table 2 The body fat content and lipid metabolism according to free T3, free T4, and TSH

\begin{tabular}{|c|c|c|c|c|c|c|c|c|c|c|c|c|}
\hline \multirow[t]{2}{*}{ Parameter } & \multicolumn{3}{|l|}{ Free T3 } & \multirow{2}{*}{$\begin{array}{l}P \\
\text { value }\end{array}$} & \multicolumn{3}{|l|}{ Free T4 } & \multirow{2}{*}{$\begin{array}{l}P \\
\text { value }\end{array}$} & \multicolumn{3}{|l|}{ TSH } & \multirow{2}{*}{$\begin{array}{l}P \\
\text { value }\end{array}$} \\
\hline & $(\leq 2.37)$ & $\begin{array}{l}(2.39- \\
2.74)\end{array}$ & $(\geq 2.76)$ & & $(\leq 0.96)$ & $\begin{array}{l}(0.97- \\
1.07)\end{array}$ & $(\geq 1.09)$ & & $(\leq 1.09)$ & $\begin{array}{l}(1.11- \\
1.75)\end{array}$ & $(\geq 1.88)$ & \\
\hline$\overline{\mathrm{BMI}}$ & $\begin{array}{l}23.16 \\
(2.38)\end{array}$ & $\begin{array}{l}25.92 \\
(2.72)^{a}\end{array}$ & $26.75(3.86)^{a}$ & $\begin{array}{l}< \\
0.001\end{array}$ & $\begin{array}{l}24.19 \\
(2.93)\end{array}$ & $\begin{array}{l}26.77 \\
(3.59)^{\mathrm{a}}\end{array}$ & $\begin{array}{l}24.92 \\
(3.26)\end{array}$ & 0.033 & $\begin{array}{l}24.25 \\
(2.55)\end{array}$ & $\begin{array}{l}25.42 \\
(4.04)\end{array}$ & $\begin{array}{l}26.20 \\
(3.32)\end{array}$ & 0.163 \\
\hline WHR & $0.91(0.05)$ & $0.93(0.05)$ & $0.95(0.05)$ & 0.125 & $0.92(0.04)$ & $\begin{array}{l}0.95 \\
(0.06)^{a}\end{array}$ & $\begin{array}{l}0.92 \\
(0.05)^{b}\end{array}$ & 0.030 & $0.91(0.05)$ & $0.93(0.05)$ & $0.94(0.05)$ & 0.163 \\
\hline BFP & $\begin{array}{l}21.85 \\
(4.97)\end{array}$ & $\begin{array}{l}22.50 \\
(5.46)\end{array}$ & $\begin{array}{l}26.69 \\
(5.95)^{a, b}\end{array}$ & 0.008 & $\begin{array}{l}21.99 \\
(5.29)\end{array}$ & $\begin{array}{l}24.83 \\
(5.91)\end{array}$ & $\begin{array}{l}24.40 \\
(6.10)\end{array}$ & 0.221 & $\begin{array}{l}22.66 \\
(5.63)\end{array}$ & $\begin{array}{l}22.88 \\
(6.04)\end{array}$ & $\begin{array}{l}25.69 \\
(5.56)\end{array}$ & .158 \\
\hline VFC & $\begin{array}{l}101.54 \\
(20.25)\end{array}$ & $\begin{array}{l}106.66 \\
(26.34)\end{array}$ & $\begin{array}{l}123.05 \\
(30.29)^{\mathrm{a}, \mathrm{b}}\end{array}$ & 0.019 & $\begin{array}{l}104.20 \\
(20.65)\end{array}$ & $\begin{array}{l}122.16 \\
(29.07)\end{array}$ & $\begin{array}{l}105.64 \\
(28.70)\end{array}$ & 0.050 & $\begin{array}{l}106.66 \\
(23.35)\end{array}$ & $\begin{array}{l}110.45 \\
(31.19)\end{array}$ & $\begin{array}{l}114.89 \\
(27.39)\end{array}$ & 0.613 \\
\hline TG & $1.55(0.87)$ & $2.01(1.65)$ & $2.41(1.94)$ & 0.184 & $2.35(2.04)$ & $1.71(1.26)$ & $1.92(1.31)$ & 0.393 & $1.91(1.73)$ & $1.67(1.12)$ & $2.41(1.77)$ & 0.291 \\
\hline TC & $4.72(1.47)$ & $4.43(0.98)$ & $4.98(1.37)$ & 0.383 & $4.54(1.14)$ & $4.38(1.04)$ & $5.23(1.56)$ & 0.069 & $4.04(0.75)$ & $\begin{array}{l}4.85 \\
(1.28)^{a}\end{array}$ & $\begin{array}{l}5.26 \\
(1.48)^{a}\end{array}$ & 0.005 \\
\hline $\mathrm{HDL}$ & $0.99(0.22)$ & $0.97(0.21)$ & $1.12(0.30)$ & 0.082 & $1.00(0.21)$ & $0.95(0.24)$ & $1.13(0.28)$ & 0.068 & $0.90(0.19)$ & $\begin{array}{l}1.12 \\
(0.23)^{a}\end{array}$ & $\begin{array}{l}1.06 \\
(0.28)^{\mathrm{a}}\end{array}$ & 0.010 \\
\hline LDL & $2.93(1.26)$ & $2.49(0.65)$ & $2.74(0.86)$ & 0.336 & $2.41(0.75)$ & $2.57(0.68)$ & $\begin{array}{l}3.20 \\
(1.22)^{a, b}\end{array}$ & 0.014 & $2.39(0.74)$ & $2.81(0.83)$ & $2.98(1.19)$ & 0.105 \\
\hline Adiponectin & $5.03(0.67)$ & $\begin{array}{l}5.56 \\
(0.71)^{a}\end{array}$ & $5.46(0.72)^{a}$ & 0.037 & $5.05(0.62)$ & $5.56(0.77)$ & $5.43(0.70)$ & 0.052 & $5.22(0.76)$ & $5.33(0.71)$ & $5.50(0.71)$ & 0.425 \\
\hline Leptin & $3.04(0.33)$ & $3.25(0.36)$ & $3.22(0.38)$ & 0.123 & $3.07(0.34)$ & $3.29(0.35)$ & $3.15(0.38)$ & 0.129 & $3.08(0.40)$ & $3.20(0.35)$ & $3.23(0.34)$ & 0.339 \\
\hline Visfatin & $\begin{array}{l}29.58 \\
(3.59)\end{array}$ & $\begin{array}{l}28.56 \\
(3.10)\end{array}$ & $29.26(2.82)$ & 0.566 & $\begin{array}{l}29.98 \\
(3.67)\end{array}$ & $\begin{array}{l}27.86 \\
(2.73)\end{array}$ & $\begin{array}{l}29.59 \\
(2.71)\end{array}$ & 0.058 & $\begin{array}{l}29.29 \\
(3.45)\end{array}$ & $\begin{array}{l}29.13 \\
(2.49)\end{array}$ & $\begin{array}{l}29.01 \\
(3.59)\end{array}$ & 0.959 \\
\hline TNF-a & $\begin{array}{l}16.26 \\
(2.32)\end{array}$ & $\begin{array}{l}18.63 \\
(2.21)^{a}\end{array}$ & $19.06(2.16)^{a}$ & $\begin{array}{l}< \\
0.001\end{array}$ & $\begin{array}{l}17.01 \\
(2.26)\end{array}$ & $\begin{array}{l}18.76 \\
(2.68)\end{array}$ & $\begin{array}{l}18.20 \\
(2.40)\end{array}$ & 0.062 & $\begin{array}{l}17.24 \\
(2.83)\end{array}$ & $\begin{array}{l}18.31 \\
(2.32)\end{array}$ & $\begin{array}{l}18.42 \\
(2.32)\end{array}$ & 0.234 \\
\hline IL-6 & $\begin{array}{l}10.88 \\
(1.57)\end{array}$ & $\begin{array}{l}11.79 \\
(1.47)^{\mathrm{a}}\end{array}$ & $12.08(1.11)^{\mathrm{a}}$ & 0.015 & $\begin{array}{l}11.04 \\
(1.57)\end{array}$ & $\begin{array}{l}12.32 \\
(1.37)^{\mathrm{a}}\end{array}$ & $\begin{array}{l}11.40 \\
(1.17)^{b}\end{array}$ & 0.009 & $\begin{array}{l}11.45 \\
(1.43)\end{array}$ & $\begin{array}{l}11.39 \\
(1.55)\end{array}$ & $\begin{array}{l}11.92 \\
(1.41)\end{array}$ & .423 \\
\hline Homocysteine & $9.32(2.52)$ & $9.19(1.36)$ & $9.37(1.87)$ & 0.951 & $9.54(2.35)$ & $8.72(1.36)$ & $9.63(1.97)$ & 0.237 & $8.87(1.03)$ & $9.33(2.01)$ & $9.69(2.51)$ & 0.381 \\
\hline UA & $\begin{array}{l}325.45 \\
(93.30)\end{array}$ & $\begin{array}{l}333.67 \\
(94.55)\end{array}$ & $\begin{array}{l}319.35 \\
(80.30)\end{array}$ & 0.869 & $\begin{array}{l}335.73 \\
(99.80)\end{array}$ & $\begin{array}{l}307.73 \\
(89.73)\end{array}$ & $\begin{array}{l}334.36 \\
(74.49)\end{array}$ & 0.501 & $\begin{array}{l}310.41 \\
(98.37)\end{array}$ & $\begin{array}{l}338.18 \\
(90.82)\end{array}$ & $\begin{array}{l}329.23 \\
(75.74)\end{array}$ & 0.574 \\
\hline
\end{tabular}

*a: compared with lowest category of tertile with $P<0.05$; b: highest versus middle category of tertile with $P<0.05$

observed significant differences in BMI $(P=0.033)$, WHR $(P=0.030)$, LDL-C $(P=0.014)$, and IL-6 $(P=$ $0.009)$ among the FT4 categories, but there were no significant differences in BFP $(P=0.221)$, VFC $(P=0.050)$, TG $(P=0.393)$, TC $(P=0.069)$, HDL-C $(P=0.068)$, adiponectin $(P=0.052)$, leptin $(P=0.129)$, visfatin $(P=$ $0.058)$, TNF- $\alpha(P=0.062)$, homocysteine $(P=0.237)$, or uric acid $(P=0.501)$. The pairwise comparison showed the following: the lowest category of FT4 was associated with lower BMI, as compared with the middle category of FT4 (MD, -2.58 ; 95\% CI, -4.55 to $-0.61 ; P<0.05$ ); the lower category of FT4 was associated with lower WHR, as compared with the middle category of FT4 (MD, $-0.04 ; 95 \% \mathrm{CI},-0.07$ to $-0.01 ; P<0.05$ ), whereas the middle category of FT4 was associated with increased WHR, as compared with the highest category of FT4 (MD, 0.03 ; 95\% CI, 0.00 to $0.06 ; P<0.05$ ); the lowest (MD, $-0.79 ; 95 \% \mathrm{CI},-1.34$ to $-0.24 ; P<0.05)$ and middle categories (MD, -0.63 ; $95 \% \mathrm{CI},-1.18$ to -0.08 ; $P<0.05)$ of FT4 were associated with lower LDL-C, as compared with the highest category of FT4; the lowest category of FT4 was associated with lower IL-6, as compared with the middle category of FT4 (MD, $-1.29 ; 95 \%$ CI, -2.12 to $-0.45 ; P<0.05)$, whereas the middle category of FT4 was associated with increased IL-6, as compared with the highest category of FT4 (MD, 0.92; 95\% CI, 0.09 to $1.75 ; P<0.05)$. Moreover, we noted that FT4 level was positively correlated with HDL-C $(r=0.26$; $P=$ $0.038)$, LDL-C $(r=0.26 ; P=0.036)$, and adiponectin $(r=$ $0.28 ; P=0.023)$ (Table 3 ).

\section{TSH}

The distribution of body fat content and lipid metabolism according to TSH are shown in Table 2 . We noted significant differences in TC $(P=0.005)$ and HDL-C $(P=0.010)$ among the TSH categories, but there were no significant differences in BMI $(P=0.163)$, WHR $(P=$ $0.163)$, BFP $(P=0.158)$, VFC $(P=0.613)$, TG $(P=0.291)$, LDL $(P=0.105)$, adiponectin $(P=0.425)$, leptin $(P=$ $0.339)$, visfatin $(P=0.959)$, TNF- $\alpha(P=0.234)$, IL-6 $(P=$ $0.423)$, homocysteine $(P=0.381)$, or uric acid $(P=0.574)$. The pairwise comparison showed the following: the 
Table 3 Correlation analysis of thyroid hormone and body fat content and lipid metabolism

\begin{tabular}{|c|c|c|c|c|c|c|}
\hline \multirow[t]{2}{*}{ Variable } & \multicolumn{2}{|l|}{ TSH } & \multicolumn{2}{|c|}{ Free T3 } & \multicolumn{2}{|c|}{ Free T4 } \\
\hline & $\bar{r}$ & $\overline{P \text { value }}$ & $\bar{r}$ & $\overline{P \text { value }}$ & $\bar{r}$ & $P$ value \\
\hline$\overline{\mathrm{BMI}}$ & 0.19 & 0.127 & 0.45 & $<0.001$ & 0.09 & 0.487 \\
\hline WHR & 0.20 & 0.100 & 0.27 & 0.028 & 0.04 & 0.733 \\
\hline BFP & 0.20 & 0.113 & 0.33 & 0.007 & 0.18 & 0.146 \\
\hline VFC & 0.11 & 0.397 & 0.30 & 0.014 & 0.02 & 0.904 \\
\hline TG & 0.21 & 0.096 & 0.22 & 0.082 & -0.16 & 0.205 \\
\hline TC & 0.36 & 0.003 & 0.14 & 0.271 & 0.17 & 0.180 \\
\hline $\mathrm{HDL}$ & 0.13 & 0.301 & 0.19 & 0.135 & 0.26 & 0.038 \\
\hline LDL & 0.19 & 0.134 & 0.02 & 0.892 & 0.26 & 0.036 \\
\hline Adiponectin & 0.08 & 0.515 & 0.25 & 0.045 & 0.28 & 0.023 \\
\hline Leptin & 0.16 & 0.204 & 0.17 & 0.169 & 0.16 & 0.202 \\
\hline Visfatin & 0.02 & 0.902 & -0.12 & 0.333 & -0.01 & 0.920 \\
\hline TNF-a & 0.08 & 0.506 & 0.47 & $<0.001$ & 0.24 & 0.056 \\
\hline IL-6 & 0.01 & 0.913 & 0.32 & 0.008 & 0.05 & 0.696 \\
\hline Homocysteine & 0.13 & 0.300 & -0.05 & 0.675 & 0.02 & 0.868 \\
\hline UA & 0.07 & 0.580 & 0.03 & 0.827 & 0.05 & 0.686 \\
\hline
\end{tabular}

*BFP: body fat percentage; BMI: body mass index; HDL: high-density lipoprotein; LDL: low-density lipoprotein; WHR: waist-hip ratio; TC: total cholesterol; TG: triglyceride; UA: uric acid; VFC: visceral fat content

lowest category of TSH was associated with lower TC, as compared with the middle (MD, $-0.81 ; 95 \% \mathrm{CI},-$ 1.54 to $-0.08 ; P<0.05)$ and highest categories (MD, 1.22 ; $95 \% \mathrm{CI},-1.95$ to $-0.49 ; P<0.05)$ of $\mathrm{TSH}$; the lowest category of TSH was associated with lower HDL-C, as compared with the middle (MD, $-0.22 ; 95 \% \mathrm{CI},-$ 0.37 to $-0.08 ; P<0.05)$ and highest categories (MD, 0.16 ; $95 \% \mathrm{CI},-0.30$ to $-0.02 ; P<0.05)$ of TSH. Furthermore, the TSH level was positively correlated with TC $(r=0.36 ; P=0.003)$.

\section{Discussion}

This study assessed the associations of thyroid hormones with body fat content and lipid metabolism in euthyroid male patients with T2DM. This study found significant differences in BMI, BFP, VFC, adiponectin, TNF- $\alpha$, and IL-6 among the different FT3 groups; in BMI, WHR, LDL-C, and IL-6 among the different FT4 groups; and in TC and HDL-C among the different TSH groups. Moreover, FT3 was positively related to BMI, WHR, BFP, VFC, adiponectin, TNF- $\alpha$, and IL-6. FT4 was positively correlated with HDL-C, LDL-C, and adiponectin. TSH was positively correlated with TC.

Studies have reported that thyroid metabolism is closely related to obesity and T2DM even in euthyroid patients [11-14]. However, the complexity of the mechanism is highlighted by different results depending on the populations studied. A previous study from China in patients with diabetes showed that TSH was higher in female than male patients and that TSH was positively associated with serum TC and LDL-C in women with T2DM [15]. In this study, all the subjects were male, and the interference of sex hormones on thyroid function and lipid metabolism could be excluded. Javed et al. observed that hyperthyrotrophin was present in obese adolescents with normal thyroid function [7]. A previous study showed that progressive central fat accumulation was associated with an increase in both FT3 and TSH in women, but this was independent of insulin resistance [16]. This result merits further examination in men. However, the details of the differences in body fat content and lipid metabolism among various thyroid hormones in euthyroid male patients with T2DM was unknown. Therefore, this cross-sectional study was performed to explore any potential role of thyroid hormones on body fat content and lipid metabolism in euthyroid male patients with T2DM.

We observed that FT3 was positively related to BMI, WHR, BFP, VFC, adiponectin, TNF- $\alpha$, and IL-6 in euthyroid male patients with T2DM. Patients with T2DM presented with long-term absolute or relative insulin deficiency, reduced thyroid iodine uptake, poor thyroid function, and damaged structure [17]. Moreover, thyroxine under the action of type 2 iodothyronine deiodinases could produce FT3, and FT3 could inactivated under the action of type 3 iodothyronine deiodinases. The regulate gene transcription and protein expression through FT3 binds to the thyroid hormone nuclear receptor could affect the development, homeostasis, and regeneration of skeletal muscles [18]. Interesting, we noted the BMI, WHR, and IL-6 was high in the middle FT4 category, while the significant difference mainly observed between middle and lowest FT4 categories. Moreover, our study found that FT4 was positively correlated with HDL-C, LDL-C, and adiponectin. The reason for this could be there was no information on adiposity or muscularity, which could bias the potential correlation between FT4 and LDL-C [19]. Moreover, the association of FT4 and lipid metabolism could mediated by intricate sensing and feedback systems acted at the physiological, metabolic, molecular, and transcriptional levels in liver [20]. Finally, the difference between FT3 and FT4 on body fat content and lipid metabolism could explained by the production process of FT3 and FT4, and the potential role of FT3:FT4 ratio on body fat content and lipid metabolism in euthyroid male patients with T2DM should be evaluated in further large-scale prospective studies.

Importantly, we noted that TSH was positively correlated with $\mathrm{TC}$, but it was not associated with body fat content. Thyroid microstructure disorder exists in patients with T2DM with normal thyroid hormone levels, and the degree of disorder is related to blood glucose level and the insulin resistance index [21]. Adipose tissue 
is an organ that actively participates in the balance of energy metabolism. Adipose tissue can secrete many adipocytokines to regulate its own functions and that of other tissues, such as adiponectin, leptin, and visfatin. $\mathrm{Lu}$ et al. believed that TSH was an important regulator of adipocyte differentiation and TSH may act on adipocytes expressing TSH, thus changing the growth and differentiation of adipocytes and regulating the secretion of various adipokines in adipocytes [22]. However, in this study, TSH was not correlated with body fat content, which may be related to the limitations of the study such as the small number of samples. A larger sample size would allow further quartile analysis.

Several limitations of this study should be acknowledged. First, this study was cross-sectional, and the causality associations of thyroid hormones with body fat content and lipid metabolism could not be established. Second, the severity of T2DM was not addressed, which needed further adjustment of the HbA1c levels. Third, the background treatment strategies for T2DM was not addressed, which might play an important role on body fat content and lipid metabolism. Further prospective study should be performed to verify the causality associations of thyroid hormones with body fat content and lipid metabolism in patients with T2DM.

\section{Conclusion}

This study found that thyroid hormone was positively correlated with body fat content and lipid metabolism in euthyroid male patients with T2DM.

\section{Abbreviations}

T2DM: Type 2 diabetes mellitus; TSH: Thyroid stimulating hormone; FT3: Free triiodothyronine; FT4: Free thyroxine; SCH: Subclinical hypothyroidism; BMI: Body mass index; MBP: Mean blood pressure; HDL-C: High density lipoprotein; LDL-C: Low density lipoprotein; HOMA-IR: Insulin resistance index

\section{Acknowledgements}

None.

\section{Authors' contributions}

S.X. and C.L. conceived and designed the experiments. S.X., W.R., Z.D. and H.Y. performed the experiments. S.X. analyzed the data and wrote the paper. S.X., and W.R. contributed reagents/materials/analysis tools. All author shave read and approved the final version of this manuscript.

\section{Funding}

The study was supported by Zhejiang Medical and Health Science and Technology Project (2017KY729).

\section{Availability of data and materials}

The datasets used and/or analysed during the current study are available from the corresponding author on reasonable request.

\section{Declarations}

\section{Ethics approval and consent to participate}

The study protocol was conducted according to the principles expressed in the Declaration of Helsinki. This study was approved by the ethics committee of Lishui Municipal Central Hospital (ethics no. 2016-26). All patients provided informed consent for the inclusion in the study.
Consent for publication

Not applicable.

\section{Competing interests}

The authors declared that they have no conflict of interest.

\section{Author details}

'Department of Endocrinology, Lishui Hospital of Traditional Chinese Medicine, No. 800 Zhongshan Street, Liandu District, Lishui, Zhejiang 323000, China. ${ }^{2}$ Department of Cardiovascular Medicine, Lishui Hospital of Traditional Chinese Medicine, Lishui, Zhejiang, China. ${ }^{3}$ Department of Clinical Laboratory, Lishui Municipal Central Hospital, Lishui, Zhejiang, China. ${ }^{4}$ Department of Endocrinology, Lishui Municipal Central Hospital, Lishui, Zhejiang, China.

Received: 10 June 2021 Accepted: 18 November 2021

Published online: 06 December 2021

\section{References}

1. Jaacks LM, Siegel KR, Gujral UP, Narayan KMV. Type 2 diabetes: a 21st century epidemic. Best Pract Res Clin Endocrinol Metab. 2016;30(3):331-43. https://doi.org/10.1016/j.beem.2016.05.003.

2. Bommer C, Heesemann E, Sagalova V, Manne-Goehler J, Atun R, Bärnighausen T, et al. The global economic burden of diabetes in adults aged 20-79years: a cost-of-illness study. Lancet Diabetes Endocrinol. 2017; 5(6):423-30. https://doi.org/10.1016/S2213-8587(17)30097-9.

3. DeFronzo RA. Pathogenesis of type 2 diabetes mellitus. Med Clin North Am. 2004;88(4):787-835. https://doi.org/10.1016/j.mcna.2004.04.013.

4. Guo S. Insulin signaling, resistance, and the metabolic syndrome: insights from mouse models into disease mechanisms.J Endocrinol. 2014:220(2):T123. https://doi.org/10.1530/JOE-13-0327.

5. Maffi P, Secchi A. The burden of diabetes: emerging data. Dev Ophthalmol. 2017;60:1-5. https://doi.org/10.1159/000459641.

6. Yazici D, Sezer H. Insulin resistance, obesity and lipotoxicity. Adv Exp Med Biol. 2017;960:277-304. https://doi.org/10.1007/978-3-319-48382-5_12.

7. Javed A, Balagopal PB, Vella A, Fischer PR, Piccinini F, Dalla Man C, et al. Association between thyrotropin levels and insulin sensitivity in euthyroid obese adolescents. Thyroid. 2015;25(5):478-84. https://doi.org/10.1089/thy.2 015.0005 .

8. Iwen KA, Schroder E, Brabant G. Thyroid hormones and the metabolic syndrome. Eur Thyroid J. 2013;2(2):83-92. https://doi.org/10.1159/000351249.

9. Kleinau G, Biebermann H. Constitutive activities in the thyrotropin receptor: regulation and significance. Adv Pharmacol. 2014;70:81-119. https://doi. org/10.1016/B978-0-12-417197-8.00003-1.

10. Williams GR. Extrathyroidal expression of TSH receptor. Ann Endocrinol (Paris). 2011;72(2):68-73. https://doi.org/10.1016/j.ando.2011.03.006.

11. Muscogiuri G, Sorice GP, Mezza T, Prioletta A, Lassandro AP, Pirronti T, et al. High-normal TSH values in obesity: is it insulin resistance or adipose tissue's guilt. Obesity (Silver Spring). 2013;21(1):101-6. https://doi.org/10.1002/oby.2 0240

12. Erdogan M, Canataroglu A, Ganidagli S, Kulaksizoglu M. Metabolic syndrome prevalence in subclinic and overt hypothyroid patients and the relation among metabolic syndrome parameters. J Endocrinol Investig. 2011;34(7): 488-92. https://doi.org/10.3275/7202

13. Ozair M, Noor S, Raghav A, Siddiqi SS, Chugtai AM, Ahmad J. Prevalence of thyroid disorders in north Indian type 2 diabetic subjects: a cross sectional study. Diabetes Metab Syndr. 2018;12(3):301-4. https://doi.org/10.1016/j. dsx.2017.12.016

14. Zhou CP. Study on the relationship between subclinical hypothyroidism and diabetic vascular complications in type 2 diabetes mellitus. New World of Diabetes. 2017;20:69-70.

15. Zhang $Y, L$ L P, Zhang L, Xiao X. Association between lipids profile and thyroid parameters in euthyroid diabetic subjects: a cross-sectional study. BMC Endocrinol Disord. 2015;15(1):12. https://doi.org/10.1186/s12902-0150008-3.

16. De Pergola G, Ciampolillo A, Paolotti S, et al. Free triiodothyronine and thyroid stimulating hormone are directly associated with waist circumference, independently of insulin resistance, metabolic parameters and blood pressure in overweight and obese women. Clin Endocrinol. 2007; 67(2):265-9. https://doi.org/10.1111/j.1365-2265.2007.02874.x. 
17. Kalra S, Aggarwal S, Khandelwal D. Thyroid dysfunction and type 2 diabetes mellitus: screening strategies and implications for management. Diabetes Ther. 2019;10(6):2035-44. https://doi.org/10.1007/s13300-019-00700-4.

18. Yen PM. Physiological and molecular basis of thyroid hormone action. Physiol Rev. 2001;81(3):1097-142. https://doi.org/10.1152/physrev.2001.81.3.1 097.

19. Roef G, Lapauw B, Goemaere S, Zmierczak HG, Toye K, Kaufman JM, et al. Body composition and metabolic parameters are associated with variation in thyroid hormone levels among euthyroid young men. Eur J Endocrinol. 2012;167(5):719-26. https://doi.org/10.1530/EJE-12-0447.

20. Beukhof CM, Massolt ET, Visser TJ, Korevaar TIM, Medici M, de Herder WW, et al. Effects of thyrotropin on peripheral thyroid hormone metabolism and serum lipids. Thyroid. 2018;28(2):168-74. https://doi.org/10.1089/thy.2017. 0330 .

21. Liu Z, Liu Q, Wu L. A study of thyroid axis microdisorders in type 2 diabetes mellitus patients with normal thyroid function. Hebei Med. 2017;39:2109-12.

22. Lu S, Guan Q, Liu Y, Wang H, Xu W, Li X, et al. Role of extrathyroidal TSHR expression in adipocyte differentiation and its association with obesity. Lipids Health Dis. 2012;11(1):17. https://doi.org/10.1186/1476-511X-11-17.

\section{Publisher's Note}

Springer Nature remains neutral with regard to jurisdictional claims in published maps and institutional affiliations.

Ready to submit your research? Choose BMC and benefit from:

- fast, convenient online submission

- thorough peer review by experienced researchers in your field

- rapid publication on acceptance

- support for research data, including large and complex data types

- gold Open Access which fosters wider collaboration and increased citations

- maximum visibility for your research: over $100 \mathrm{M}$ website views per year

At BMC, research is always in progress.

Learn more biomedcentral.com/submissions 